\title{
Research on the Path of Improving the Practical Ability of Full-time Professional Accounting Master
}

\author{
Jing Xu, Chuang Gao \\ Harbin University of Commerce, Harbin, Heilongjiang, China \\ Harbin University of Commerce, Harbin, Heilongjiang, China \\ xujing2011@163.com, gaochuangbaby@126.com
}

Keywords: Full-time professional accounting master, practical ability, Improvement path

Abstract: The enrollment of full-time professional accounting master loosens the requirements of 2-year or more relative work experiences. As a result, most qualified students are fresh graduates without working experience. How to train students' practical ability comes to the first priority. Based on the appropriate training goal, the article recommends specific solutions including various aspect of cultivation direction, model of teaching, content of courses and tutor team in order to improve the practical ability of full-time professional accounting master.

\section{Introduction:}

The development of social economy and the continuous improvement of the capital market call for senior accountant, the requirements for the quality and ability is becoming more and more obvious. However, senior account education is insufficient in our country. To meet with the social requirements, our country opened up master degree of professional accounting (MPAcc) in 2009. Considering the fresh graduates have no working experience, it is vital to improve the practical ability. The cultivation of practical ability is the key point to realize the training goal.

\section{Analysis of Full-time Professional Accounting Master's Present Training Situation}

The Quantity of Training Units is a Growing Trend: Professional accounting master degree education officially started from 2004 in our country, roughly experienced the breeding period of 2004-2010 and began to development in 2011. Professional accounting master gradually get general recognition of the institutions of higher learning and employers. The quantity of training units develops rapidly and presents a growing trend, which have made a great contribution for our country's senior accounting personnel training. The quantity of training units in these years is shown in Fig.1

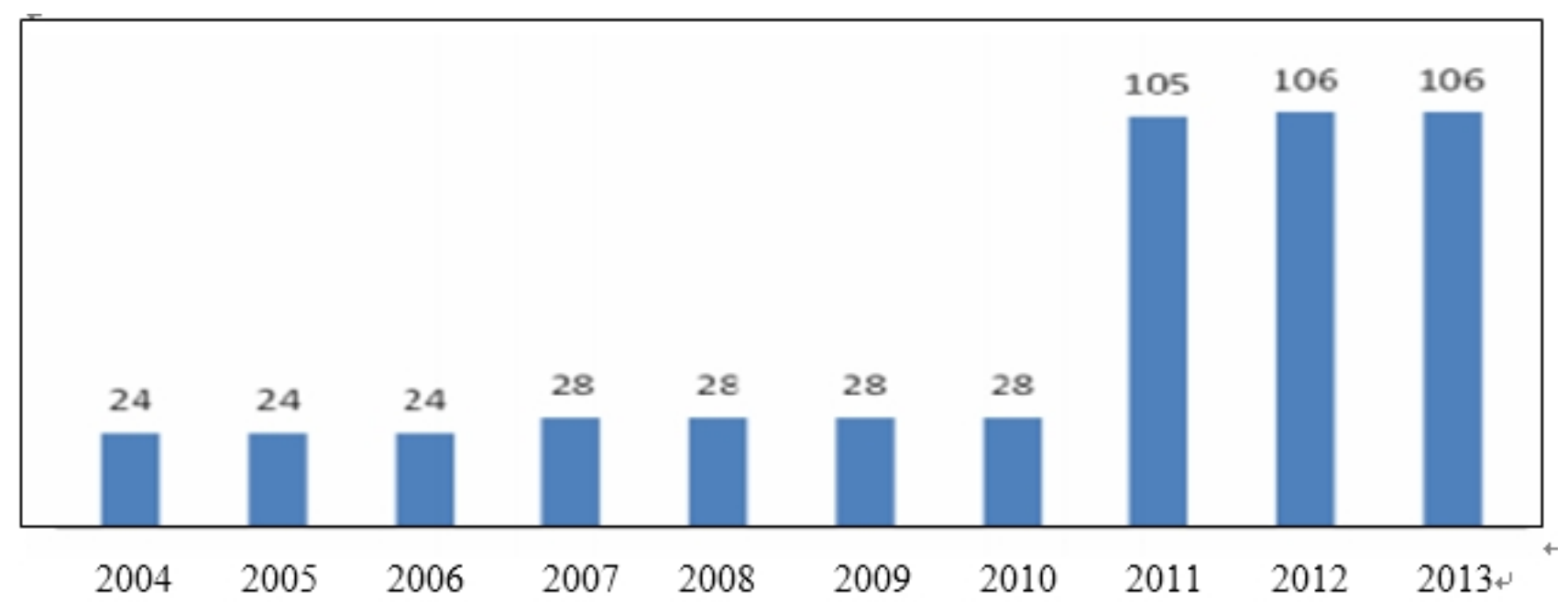

Fig.1. the Quantity of Training Units 
Training Scale is Growing Rapidly: Since 2009, when the country carried out the full-time undergraduate course admission majoring in professional accounting master degree after undergraduate course for the first time, the number of admitted students of MPAcc have rapidly increased. Enrollments increased from 2784 in 2011 to nearly 5000 in 2015. Professional accounting master's programs in China have experienced years of development and largely accepted by students and society in general.

Clearly Position of the Training Target: Clear training objective determines the basis of the teaching contents, teaching methods. Full-time master of professional accounting training could achieve the desired effect under the guidance of the training objectives----the realistic need. Master degree of professional accounting emphasizes the applicability and professional background, so the core of the training should be concentrated on the vocational comprehensive ability. In our country, master of professional accounting objectives can generally be divided into three aspects: professional ethics, knowledge, competence requirements. Specialized knowledge includes modern accounting, auditing, financial management and related fields of knowledge; Capacity requirements includes the enterprising spirit, innovation consciousness, strategic awareness, problem solving skills, ability to learn, etc. Based on the above spirit, combining the practical education of MPAcc, training objectives can be expressed as training persons for large and medium-sized enterprises, financial institutions, accounting firms and governments with the abilities in mastering professional accounting knowledge and applying required skills learned from relative field, this kind of talents can adapt to fickle business environment and solve complicated economic issues. Meanwhile, they should have the potential to be the intermediate and senior management positions.

\section{The Bottleneck of Cultivating the Ability of Application in the Training Process}

The Education System of Professional Accounting Master is not Perfect: The educational objectives of training units are nearly same with the academic degree commission. But compared with other countries, the ability of application requested in our country is not specific, and for a long time, accounting education in our country highlights the importance of imparting knowledge and downplays the role of cultivating ability. Meanwhile, research on profession framework has just started, so the accounting education system which is targeted in the ability training is not sound now.

The Curriculum Design Lacks the Characteristics of practical ability Training: Compared with the curriculum design and teaching contents in foreign countries, it is not difficult to find that professional master degree education highlights the practical abilities, effectiveness and applicability compared with academic master degree. However, training scheme, especially the core curriculum set at present is limited in colleges and universities, even similar to academic graduate student. And curriculum in different types, different levels of school is almost designed similarly, in which way cannot meet the different needs of senior accounting who are talented for application. In fact, the overall proportion of practice is rather small in most of colleges and universities for which accounts 6 credits only,

Professional Practice lag relatively: According the original intention of professional accounting master program, it lays particular emphasis on the vocational values and the store of professional knowledge so as to enhance the comprehensive abilities. Compared with academic master, the most prominent feature is that professional master pays attention to practical teaching. The practice teaching base construction is also weak and opportunities for students to experience the accounting practice in-depth are insufficient. Students cannot combine the theory with practice in enterprises and improve their ability of analysis and application. 


\section{Measures to Improve the practical ability of Full-time Professional Accounting Master}

Set Training Direction based on Social Demand: At present, the professional directions in colleges can basically reflect the market demand, the directions mainly concentrated on the aspect of accounting, auditing, financial management, CFO and CPA, etc., other characteristic directions include the value assessment and securities analysis, forensic accounting, international accounting, public finance and non-profit organization accounting, financial engineering, etc.. In the early stage of the professional accounting master's training, all units should do according their abilities, simply pursuing new and perfection on the curriculum set is obviously wrong.

Reform the Teaching Mode and Teaching Content: Full-time professional master's training should focus on the cultivation of practical ability. The percentage of practical course should be added more in the training plan. Add more practical teaching in the curriculum which is derived from the literature so as to make up the deficiency in practical experience. Courses of professional degree are basically arranged in the first year and the trainees are mainly fresh graduate students, they seldom participate in the tutor's projects. Eventually, they are probably not aware of the purpose of theoretical study and how to use what have learned. For professional degree, the real purpose of theoretical teaching is applying theory in practice,so colleges should combine the theoretical teaching with practical training, in this case,the case analysis is a feasible method. At the same time, colleges should increase the percentage of professional accounting courses and bilingual teaching courses to cultivate senior international accounting personnel.

Strengthen the Construction of the Tutor: To form tutor team both theoretical and strong practical, the training units can hire teachers from the corporate and encourage teachers to take a part-time job in corporation. Colleges and universities should determine the guide way according to the strength and the characteristics of students. Diversity guidance should be promoted, students can benefit from collective cultivation which combines professors and appropriate staff related to companies.

Increase the proportion of workplace learning: In the cultivating process of practical ability, it is essential to access to the enterprises for field practice. Simulation practice in school is not enough, students cannot familiar with the process of accounting work without field experience and deal with the accounting practice.Some colleges and universities neglect the process of internship in enterprises, which is extremely unfavorable for the upcoming social work. Although some colleges and universities arrange internship, unified arrangement is sufficient. Internship should be unified managed by colleges and universities to ensure that students can perform organized. On the one hand, unified management can enhance the supervision, on the other hand, students in the same company can study and interact with each other during the internship.

It is not enough to practice in company only, stratified education should be carried out during the process of training. Setting up a pattern that combines colleges and enterprises is necessary. Colleges put the investigate and survey of market-oriented demand in the first place. Make plans for cultivation based on the typical demand of enterprises.Meanwhile, curriculum which combines the features of colleges and universities can equip student with high level of skills efficiently. Under the mode of organic combination, innovation and inspiration triggered by students are more likely to have actual application value.

Emphasizes the International Concept and Strengthen the Local Education: With the augmentation of international competitiveness, there will be more domestic enterprise to expand abroad. The demand of accounting talents who are able to use bilingual and familiar with international accounting standard has increased. Therefore, professional accounting education need to adapt to the changing business environment and make sure that students can be qualified in the global range. In global economic activity, accounting personnel dealing with international business not only need strong professional quality but also can communicate with foreigners fluently, therefore, it requires the relevant accounting personnel have relatively foreign language ability, especially professional foreign 
language. Thus, the ability of reading foreign literature and the international accounting standards should be cultivated. On the other hand, due to the sustainable development of China's economy and the huge investment attraction, foreign capital is still pouring into the domestic, the international competitive advantages will greatly enhance of domestic enterprises, so it is urgent to increase the curriculum with Chinese native features on the basis of advanced foreign textbook.

Thesis Topic selection should be concentrated on the issues of accounting practice: The professional accounting master 's cultivation target is the practical ability, therefore the graduation thesis should be related with accounting practice problems as the main content. Through the writing of the graduation thesis can not only improve their ability to analyze problems and solve problems, but also solve the problem of accounting practice in our country with theory.

\section{Acknowledgments}

Project on degree and postgraduate education reform in Heilongjiang province in 2011, Training Mode and Quality Control Research on Full-time Master of Professional Accounting, Item number, JGXM_HLJ_2011070.

\section{References}

[1] Jifeng Chen, Ligang Hou, Chunhui Liu. 'Case' help professional accounting master's training mode change - review on the fourth China MPAcc education and development BBS [J]. Accounting Research. 2013(02)

[2] Hongxia Liu, Xiuting Wang. Research on the curriculum system construction of MPAcc under the concept of agile manufacturing[A]. Vol. on the 13th annual on accounting Information of the accounting society of China[C]. 2014

[3] Xuemei Zhang. Foster mechanism of MPAcc[A]. Vol.on the annual meeting in 2014 and the seventh deans' BBS of accounting schools of the professional accounting education committee in Chinese accounting association [C]. 2014 